\title{
LEGALITY AND LEGITIMACY OF LAW PROMULGATED WITHOUT PRESIDENTIAL RATIFICATION IN THE PRESIDENTIAL GOVERNMENT SYSTEM
}

\author{
Morus Maxine Sianipar*, ORCID ID: 0000-0002-8656-4389, \\ Muchamad Ali Safa'at, ORCID ID: 0000-0001-5246-4171, \\ Tunggul Anshari S. N., ORCID ID: 0000-0001-8208-9958, \\ Aan Eko Widiarto, ORCID ID: 0000-0003-3193-399X

\begin{abstract}
Brawijaya University Malang, Jl. Veteran, Ketawanggede, Kec. Lowokwaru, Kota Malang, Jawa Timur 65145, Indonesia

*Corresponding author: Morus Maxine Sianipar, maxinemorus@gmail.com
\end{abstract}

Received: 12. 22. 2021

Accepted: 02. 05. 2022

\begin{abstract}
After the first amendment to the 1945 Constitution, there was a shift in power to form laws from the President to the DPR. The power of the DPR to form laws is shared with the President because each bill is discussed jointly by the DPR and the President for mutual approval. The joint approval of the DPR and the President is the binding point for the two state institutions that produce material laws. However, there are several bills that have been mutually agreed with the DPR and the President that have not been signed by the President. After a period of thirty days has been lapsed, the mutually agreed Bill by the DPR and the President shall become Law, even without the ratification of the President, and must be promulgated. This phenomenon raises question of why the President does not ratify the Bills he has approved. This research is a normative research with a statutory, conceptual, historical and comparative approach, which is expected to provide coherence and continuity to constitutional theories, so that the process of forming laws with outputs at each stage to be with more measurable results.
\end{abstract}

Keywords: Legislation, Government system, Representative institutions.

Rezumat. După primul amendament la Constituția din 1945 a avut loc o schimbare a puterii de a forma legi, de la Președinte la DPR. Puterea DPR de a formula legi este împărtășită cu președintele, deoarece fiecare proiect de lege este discutat în comun de către DPR și președinte pentru aprobare reciprocă. Aprobarea comună a DPR și a Președintelui este punctul obligatoriu pentru cele două instituții ale statului care produc legi materiale. Cu toate acestea, există mai multe proiecte de lege care au fost agreate de comun acord cu DPR și Președintele, dar care nu au fost semnate de Președinte. După expirarea unei perioade de treizeci de zile, proiectul de lege convenit de comun acord de DPR și Președinte devine Lege, chiar și fără ratificarea Președintelui, și trebuie promulgat. Acest fenomen ridică întrebarea: de ce președintele nu ratifică proiectele de lege pe care le-a aprobat? Această lucrare este o cercetare normativă cu abordare statutară, conceptuală, istorică și comparativă, care se 
așteaptă să ofere coerență și continuitate teoriilor constituționale, astfel încât procesul de formare a legilor să aibă rezultate măsurabile.

Cuvinte cheie: Legislație, Sistem guvernamental, Instituții reprezentative.

\section{Introduction}

The People's Consultative Assembly (MPR) in the discussion of the first amendment to the 1945 Constitution argued that it was necessary to empower the People's Representative Council (DPR), to limit the President's powers, and strengthen the presidential system. Prior to the amendment to the 1945 Constitution, the DPR's authority was only to approve or disapprove of the draft law (RUU) that came from the President. The first amendment to the 1945 Constitution gave the House of Representatives (DPR) the power to make laws, and together with the President and the Regional Representatives Council (DPD) (for certain matters) discussed the Bill. Continuation of the level I discussion, a mutual agreement was reached between the DPR and the President. The momentum for achieving mutual agreement between the DPR and the President on a bill has resulted in a material law. The bill that has been mutually agreed upon will then enter the stage of ratification by the President. If within thirty days it is not ratified by the President, the Bill becomes a law and must be promulgated in accordance with Article 20 paragraph (5) of the 1945 Constitution of the Republic of Indonesia.

During the Reformation era, there were seven bills that were not ratified by the President, which were agreed by the DPR and the President at the second level plenary session of the DPR, and then promulgated, namely: Law No. 25 of 2002 concerning the Establishment of the Riau Archipelago Province, Law No. 32 of 2002 concerning Broadcasting, Law No. 18 of 2003 concerning Advocates, Law No. 17 of 2003 concerning State Finance, Law No. 24 of 2014 concerning the Election of Governors, Regents and Mayors, Law no. 2 of 2018 concerning the Second Amendment to Law No. 17 of 2014 concerning the MPR, DPR, DPD and DPRD, Law No. 19 of 2019 concerning the Second Amendment to Law No. 30 of 2002 concerning the Corruption Eradication Commission.

On the other hand, there are Laws that were ratified by the President, but in the material and formal review it was stated by the Constitutional Court was contrary to the 1945 Constitution and the Laws as a whole were declared to have no binding legal force, such as: Law No. 20 of 2002 concerning Electricity, Law No. 9 of 2009 concerning Educational Legal Entities, Law no. 7 of 2004 concerning Water Resources, Law no. 17 of 2012 concerning Cooperatives, and the last conditionally unconstitutional for two years is Law no. 11 of 2020 concerning Job Creation.

In the Decision of the Constitutional Court of the Republic of Indonesia No. 17/PUU$\mathrm{XVI} / 2018$, regarding the review of Law no. 2 of 2018 concerning the Second Amendment to Law No. 17 of 2014 concerning the MPR, DPR, DPD and DPRD against the 1945 Constitution, the Government provided an explanation why they did not ratify Law no. 2 of 2018 as follows:

".. the law is a norm that has been mutually agreed upon by the Government and the DPR in accordance with Article 20 paragraph (2) of the 1945 Constitution, and that in its development the Law was not ratified by the President, then it is the choice of the President's policy which is the constitutional authority of the President as stated above. regulated in Article 20 paragraph (5) of the 1945 Constitution".

The President can choose to ratify or not to ratify the Bill according to the President's subjective considerations in accordance with the corridor provided by Article 20 paragraph 
(5) of the 1945 Constitution of the Republic of Indonesia. If this is the case, it raises the question of what was the original intent of the MPR to include Article 20 paragraph (5) of the 1945 Constitution in the second amendment to the Constitution 1945, what is the function of ratification in the lawmaking process, how is the legality and legitimacy of laws promulgated without the approval of the President. This is a normative research method, the approach taken is a statutory approach, a conceptual approach, a historical approach and a comparative approach.

Based on the background described above, it can be formulated the problem to be studied as follows:

1. What is the legislative ratio of Article 20 paragraph (5) of the 1945 Constitution of the Republic of Indonesia?

2. What is the background of the Bill which was not ratified by the President?

3. What is the legality and legitimacy of a Law that is not ratified by the President?

\section{Results and Discussion}

Legality and Legitimacy

Legality and legitimacy are two different concepts but are intertwined with one another. The development of the rule of law concept in the nineteenth century gave birth to the principle of legality which is fundamental to legal or procedural positivism. Legality in English is strict adherence to law prescription or doctrine, the quality of being legal, the validity of an action. The principle of legality is one of the main principles of the rule of law and is the basis for every government and state administration, especially for the rule of law in the continental system. Often formulated specifically in the expression "Het beginsel van wetmatigheid van bestuur". Sjachran Basah, as quoted by Ridwan (2007), said that the principle of legality means an effort to create a harmonious integral duet between the understanding of the rule of law and the understanding of people's sovereignty based on the monodualistic principle as pillars, which are essentially constitutive in nature [1].

The concept of the rule of law in the 1945 Constitution was originally contained in the Elucidation of the 1945 Constitution, not in the body of Law. After the third amendment, the concept of the rule of law became a constitutional norm as regulated in Article 1 paragraph (3) of the 1945 Constitution of the Republic of Indonesia. Thus, the principle of legality is a constitutional norm in the administration of the state. Constitutional Court in Decision No. 25/PUU-XIII/2015 regarding the review of Law no. 30 of 2002 concerning the Corruption Eradication Commission, explains the concept of the rule of law, as follows:

".. three substances that become the basic principles of the rule of law, namely (1) that in a state of law the government (in a broad sense) is limited by law, (2) that in a state of law formal legality applies, and (3) that in a state of law, the law governs, not people."

As the opinion of Sjachran Basah, thus, in the formation of laws at the same time also involves legitimacy. Legitimacy is lawfulness [2]. Schmitt (2004) adds to the idea of legitimacy with "consent" or approval. He formulated consent not in terms of active compliance but in the negative connotation of "right to resistance" [3]. Rousseau (1999) said that every law requires the citizen's consent to every law, even though the passage of the law is met with resistance, and even though the law punishes every citizen who violates it [4]. So that public participation in the process of forming laws is important in order its implementation does not get rejected. Habermas in his discourse theory opens space for public participation through intersubjective communication that is reflective in nature 
demanding rational and argumentative reasons. Habermas interprets the classical principle of democracy as the reciprocal relationship of administrative and communicative power [5]. Deliberative democracy or also called discursive democracy in the Indonesian constitution basically has a strong constitutional basis in the fourth principle of Pancasila, namely: Democracy led by wisdom in deliberation/representation.

Just as the rule of law is a constitutional norm, so the people's sovereignty is a constitutional norm which before the amendment to the 1945 Constitution was carried out entirely by the MPR, after the changes were carried out according to the Constitution. These two constitutional norms are also intertwined, providing an understanding that Indonesian democracy is carried out according to the provisions of the applicable laws and regulations.

\section{Legality and Legitimacy of Legal Norms}

Norm is a measure that must be obeyed by a person in relation to others or with the environment [6]. Joseph Raz (2002) in Practical Reason and Norms said that the equivalent of the word norm is a rule. In social life there are many norms that regulate a person's behavior and actions, such as religious norms, moral norms, legal norms and so on. There is a difference between legal norms and other norms, where legal norms are heteronomous, namely legal norms that come from outside a person, while other norms are autonomous, where these norms come from within a person [7]. Legal norms contain orders that are abstract, addressed (addressat) or binding on everyone (general), and apply continuously (dauerhafting), not limited by time, until the regulation is revoked or replaced with a new regulation. Legal norms that are abstract, general and apply continuously are legal norms that are included in statutory regulations. Constitutional Court in Decision No. 85/PUU$\mathrm{XI} / 2013$ regarding the review of Law no. 7 of 2004 concerning Water Resources to the 1945 Constitution, explains that:

"Legal norms recognize the existence of a hierarchy or arrangement of norms, in which the 1945 Constitution occupies the highest position. In the perspective of the arrangement of legal norms, the 1945 Constitution is a measure of the validity and legitimacy of the laws and regulations beyond."

According to Kelsen (2005), law is a system of norms, a dynamic legal order. Law as a system of dynamic norms (nomodynamics) is formed and abolished by the competent institutions or authorities, not seeing the content of the norm but seeing the aspect of its application or formation [8]. Law is valid if it is made by an institution or authority authorized to form it and is sourced and based on higher norms, so that lower norms (inferior) can be formed by higher norms (superior), and the law is tiered and layered to form a hierarchy. The hierarchical system shows the levels of norm abstraction. As a result, basic norms are at the highest level of abstraction, which play in the border area between law and morals [9].

Adolf Merkel argued that a legal norm always has two faces (das Doppelté Rechtsantliz). A legal norm upwards is sourced and based on the norms above it, but downwards it also becomes the source and becomes the basis for the legal norms below it, so that a legal norm has a relative validity period (rechtskracht), because of its validity period a legal norm that depends on the legal norms that are above it. Hans Nawiasky, in addition, said that the legal norms of a country are also grouped, and the grouping of legal norms in a country consists of four major groups, Group I: State Fundamental Norms (Staasfundalmentalnorm), Group II: Basic Rules of the State (Staatsgrundgesetz), Group III: 
Formal law (Formell Gesetz), Group IV: Implementing Rules and Autonomous Rules (Verordnung \& Autonome Satzung) [6].

In the history of the Indonesian state administration, the hierarchy of laws and regulations from 1950 to 2011 is presented in the following Table 1:

Table 1

\section{Hierarchy of Legislation}

\begin{tabular}{|c|c|c|c|c|}
\hline Law No. 1 of 1950 & $\begin{array}{l}\text { MPRS Decree No. } \\
\text { XX/MPRS/1966 }\end{array}$ & $\begin{array}{l}\text { MPR Decree No. } \\
\text { III/MPR/2000 }\end{array}$ & $\begin{array}{l}\text { Law No. } 10 \text { of } \\
2004\end{array}$ & $\begin{array}{l}\text { Law No. } 12 \text { of } \\
2011\end{array}$ \\
\hline $\begin{array}{l}\text { Law and Government } \\
\text { Regulations Substituting } \\
\text { for Laws (Perpu) }\end{array}$ & 1945 constitution & 1945 constitution & $\begin{array}{l}1945 \\
\text { constitution }\end{array}$ & 1945 constitution \\
\hline $\begin{array}{l}\text { Government regulations } \\
\text { (PP) }\end{array}$ & MPR Decree & MPR Decree & Law/Perpu & MPR Decree \\
\hline \multirow[t]{9}{*}{$\begin{array}{l}\text { Ministerial } \\
\text { (Permen) }\end{array}$} & Law & Law & PP & Law/Perpu \\
\hline & Perpu & Perpu & $\begin{array}{l}\text { presidential } \\
\text { decree }\end{array}$ & PP \\
\hline & $\mathrm{PP}$ & PP & local regulation & $\begin{array}{l}\text { presidential } \\
\text { decree }\end{array}$ \\
\hline & presidential decision & $\begin{array}{l}\text { presidential } \\
\text { decision }\end{array}$ & & $\begin{array}{l}\text { provincial } \\
\text { regulations }\end{array}$ \\
\hline & local regulation & local regulation & & $\begin{array}{l}\text { district/city } \\
\text { regulations }\end{array}$ \\
\hline & $\begin{array}{l}\text { Other Implementing } \\
\text { Regulations }\end{array}$ & & & \\
\hline & Permen & & & \\
\hline & Minister's Instruction & & & \\
\hline & etc. & & & \\
\hline
\end{tabular}

Besides the validity of a legal norm, there is also efficacy. A legal norm can have validity by following the procedure for its formation, but on the other hand it has no efficacy. The efficacy in question is whether the legal norms are implemented effectively or not, whether they are obeyed and implemented. According to Hans Kelsen, the validity of an ineffective legal norm can be revoked by desuetudo. Desuetudo is a negative legal consequence of a habit. In a legal order that is as a whole effective, a separate norm that is valid but ineffective can occur, that is, it is not obeyed and is not applied even though the stipulated conditions have been met for its application. If the norm is permanently invalidated, it loses its validity by desuetude [10].

\section{Lawmaking Formation in a Presidential Government System}

Before discussing the formation of laws, we will first discuss the system of government. Discussing the system of government is talking about how the division or separation of powers between the legislature, executive and judiciary, as well as the relationship between state institutions in exercising their power in the context of carrying out the interests of the people, is discussed [11]. In an established democracy, the executive can be categorized into three main groups of government systems, namely presidential government systems, parliamentary systems of government, and semi-presidential government systems. There are three characteristics of a presidential government system, namely (1) the president is elected through general elections, (2) a fixed term of office for 
the President and the DPR, neither of them can overthrow the other, (3) there is no overlapping of positions between the executive and the legislative [12]. Besides that, the difference with the parliamentary system of government is that in a presidential system of government the head of state and head of government are combined in one person, or in other words there is no separation between the functions of the head of state and head of government in the position of the President as chief executive. Quoting the opinion of Rogelio Alicor Labalan Panao (2014), [13] that the essence of a presidential system of government is separation of power. Manan (2003), quoting Montesquieu, said that the power to form laws is legislative power, because it (only) belongs to the legislative, the law-making body/organ. The executive body does not have the power to make laws [14].

In the formation of laws, Montesquieu (1989) said executive power, as we have said, should take part in legislation by its faculty of vetoing [15]. In the United States presidential system of government, the Constitution gives legislative power to the Congress which consists of the Senate and the House of Representatives. After a Bill is passed by Congress, it is submitted to the President for signature [16]. If the President vetoes a Bill by refusing to sign it stating the reasons for his objection, the Bill will not become Law and be returned to Congress. If Congress still wants the Bill to become Law, a two-thirds (2/3) vote in favor of each chamber in Congress overpowers the President's veto. If within ten days after the Bill is submitted to the President, the President does not sign, veto, or return the Bill to Congress, the Bill becomes Law as if the President had signed the Bill.

\section{Comparison of the Formation of Laws in the Government System}

In a parliamentary system of government, the executive organically has a link with the legislature. Lijphart (2012) provides three things that distinguish a parliamentary system of government from a presidential system. First, the head of government, who may have different official titles such as Prime Minister, Chancellor, Minister-President, or, somewhat confusingly, even "President" (as in Botswana), but is generally referred to as Prime Minister, either Prime Minister and their cabinets are accountable to the legislature in the sense that they rely on the trust of the legislature and can be removed from office by a vote of no confidence or legislative criticism [17]. Second, the Prime Minister is elected by the legislature. The third difference is that in a parliamentary system there is a collective or collegial executive. In decision-making there is a high degree of collegialism, where decisions on important issues are taken by the cabinet as a whole, not only by the Prime Minister. In contrast to the presidential system of government, there is a separation of the head of state and head of government in a parliamentary system of government, as stated by Hague and Harrop (2004): Where presidential systems combine the head of state and the head of government in one person, parliamentary rule separates the two roles. Efficient leadership rests with the cabinet, premier and ministers but dignified or ceremonial leadership lies with the head of state.

The British government is a classic example of a parliamentary government based on a single party with a guaranteed majority (Wesminster Model). In accordance with Article 52 paragraph (1) of the British Constitution that the power to make laws rests with Parliament. The British Parliament with a bicameral representation system, pursuant to Article 57 paragraph (1) of the British Constitution, consists of the Head of State, the House of Commons (Lower House) and the House of Lords/Second Chamber (Higher House) [18]. In the British system of government there is a difference between the Head of State (Head of State) and 
the Executive. The Head of State is held by the Queen/King. One of the obligations of the Head of State is to ratify (assent) laws that have been approved by Parliament. Executive power is exercised by a government consisting of the Prime Minister and members of Parliament who are appointed as Ministers in the government.

Presidential and parliamentary systems of government provide a pure model of the executive's position in politics. Executive semi-presidential refers to both formats, combining the elected President with the Prime Minister and the Cabinet reporting to Parliament, so that with a semi-presidential government we enter a more varied area. The French political scientist, Duverger (1980), gives three characteristics of semi-presidential political regimes as follows: (1) the president is elected by universal suffrage; (2) the president has considerable power; (3) behind the president there is a prime minister and a minister who has executive and government powers and can remain in office only if the parliament shows no resistance to them. The executive semi-presidential system is arguably a hybrid system, seeking to marry the executive in the national focus of an elected president with a prime minister who understands all the interests represented in the assembly [19].

The Fifth French Republic (1958) is an example of an executive semi-presidential. There are two types of executive bodies in France, namely the President of the Republic and the Prime Minister. The President of the Republic, as Head of State, is elected by majority vote for a certain period of five years. The President of the Republic appoints the Prime Minister (Head of Government) who is responsible to the Parliament, and based on the recommendation of the Prime Minister, the President appoints and dismisses members of the government. The President of the Republic presides over the Council of Ministers. The French government consists of the Prime Minister and Ministers.

In law making, the 1958 French Constitution mandates that Parliament pass laws. However, according to Article 11 of the 1958 Constitution, Parliament does not have a monopoly on making laws, as the President of the Republic may propose a referendum on a Government Bill on the recommendation of the Prime Minister during the session of Parliament. In general, the right to initiate legislation rests with the Prime Minister and members of Parliament. Bills initiated by the Prime Minister are called Government Bills, and Bills initiated by members of Parliament are called Private Member's Bills. The procedure for the formation of a law has three main stages, namely the submission of a bill, examination by the Parliament and its announcement by the President of the Republic (after possible referral to the Constitutional Council for examination of its conformity with the Constitution) (Service Des Affaires Internationales Et De Defense, 2013).

\section{Formation of Laws in a Presidential Government System Based on the 1945 Constitution}

The 1945 Constitution, prior to the amendment, did not explicitly state (expressive verbis) that the state government system was a presidential system of government. In the BPUPKI meeting on July 15, 1945, Sukiman said: "...after studying the draft laws of our country, then as a final conclusion I state, the language of this draft has its own system, different systems from the laws of some of the leading countries in the world such as Dai Nippon, America, Rusland, France, and others." The founding fathers used the term "own system" because in 1945, "semi-presidential" systems such as in France, "semi-parliamentary" as in Portugal or hybrid systems such as in Sri Lanka were not yet known. The system itself is a hybrid system in which the power is dominated by the President (President dominant presidentialism). Basically, in the 1945 Constitution there is no difference between the Head 
of State and the Head of Government. The difference between the Head of State and the Head of Government is contained in the General Elucidation of the 1945 Constitution.

As a consequence of the formation of the 1945 Constitution that does not refer to the Trias Politica theory, power is divided between the executive and the judiciary as stated in Article 4 paragraph (1): The President of the Republic of Indonesia holds government power according to the Constitution, Article 5 paragraph (1): The President holds the power to make laws with the approval of the House of Representatives, and Article 24 paragraph (1): Judicial power is exercised by a Supreme Court and other judicial bodies according to law.

The procedure for the formation of laws is regulated in Article 5 paragraph (1), Article 20 and Article 21 of the 1945 Constitution. In addition to the Presidential initiative Bill which must be approved by the President, the DPR initiative Bill which has been approved by the DPR must be ratified. This is a consequence of the power to form laws rests with the President. According to Saragih (1988), that the function of ratification in Article 21 paragraph (2) is as a legality that a law is valid after being signed by the President as head of state in the presidential government system adopted by the 1945 Constitution [20].

During the Reformation era, the 1945 Constitution underwent four fundamental changes in a relatively short period of time (1999-2002). There are five points of basic agreement in the process of discussing the amendments to the 1945 Constitution, one of which emphasizes the presidential system of government. This basic agreement indirectly recognizes that the Indonesian government system is a presidential system of government. It should be underlined that according to expert opinion in a presidential system of government, there is no distinction or no need to make a distinction between the president as the position of head of state and the president as head of government. The president is the president, namely the position that holds the power of state government according to the constitution.

In the first amendment to the 1945 Constitution, there was a shift in power to form laws to the DPR (Article 20 paragraph (1) of the 1945 Constitution of the Republic of Indonesia), and together with the DPD (for certain matters) and the President to discuss the Bill. The continuation of the discussion of this Bill, if approved, will result in a joint agreement between the DPR and the President. In accordance with the provisions of Article 20 paragraph (5) of the 1945 Constitution of the Republic of Indonesia, within thirty days the President ratifies the Bill, if the President does not ratify the Bill within thirty days, the Bill becomes a law and must be promulgated. In the event that the Bill is valid after the thirty day period the Bill is not signed by the President, the sentence for ratification reads: This law is declared valid based on the provisions of Article 20 paragraph (5) of the 1945 Constitution of the Republic of Indonesia. promulgation of the text of the Act into the State Gazette of the Republic of Indonesia.

Jimly Asshiddiqie said that it is not clear what the purpose of the constitutional arrangement regarding the thirty day deadline is. Quoting Saldi Isra's opinion that the presence of Article 20 paragraph (5) weakens the provisions contained in Article 20 paragraph (4). With the existence of Article 20 paragraph (5) of the 1945 Constitution of the Republic of Indonesia, the President's constitutional obligations are reduced to constitutional rights in the ratification of the Bill into Law. With the shift from constitutional obligations to constitutional rights, the President is not worried about not ratifying the Bill into Law.

In contrast to the provisions in the 1945 Constitution (before the amendment), the 1949 RIS Constitution and the 1950 Constitution, the President's ratification of the Bill is to 
obtain the power of law or what is also known as legality. The function of ratification in the 1945 Constitution after the second amendment is not clear and only depends on the expiration of the thirty day period and the Bill is valid to become law and must be promulgated. There is no obligation for the President to give reasons for not signing the bill, which is different from the presidential system of government in the United States, if the President does not approve the Bill that has been approved by Congress, the President gives reasons for his objections as to why he does not sign the Bill.

\section{Legality and Legitimacy of Lawmaking}

In the view of legal positivism that the only law that is accepted as law is the legal system, because only this law can be ascertained in reality. Further consequences of this view are (1) law only applies because the law gets its positive form from an authorized agency, (2) in studying law only its judicial form can be seen, in other words, law as law only has a relationship with its formal form, the juridical form of the law is separated from material legal rules, (3) the legal material content does exist, but it is not seen as legal science material, because this content is considered variable and arbitrary, the legal content depends on the ethical and political situation of a country.

In order for the statutory regulations to be valid as law from a juridical point of view, these statutory regulations must be made by the competent authority. Authorized agencies are also called state institutions in Article 1 number (2) of Law no. 12 of 2011. The state institutions that make laws in accordance with the 1945 Constitution of the Republic of Indonesia are the DPR and the President. DPD has the right to submit Bills related to certain matters. However, the enactment of a law materially after obtaining joint approval from the DPR and the President.

Constitutional Court Decision No. 91/PUU-XVII/2020 regarding the formal review of Law No. 11 of 2020 concerning Job Creation, explains the formal defects in legal considerations as follows:

the requirements for the assessment of the formal examination as set out in the Constitutional Court Decision Number 79/PUU-XVII/2019, namely:

1. examination of the implementation of the procedures or procedures for the formation of laws, both in the discussion and in making decisions on the draft of a law into law;

2. examination of the form or systematic law;

3. examination regarding the authority of the institution that makes decisions in the process of forming the law; and

4. testing of other things that do not include material testing.

All stages and standards as described and considered above, will be used to assess the validity of the formalities of the formation of laws that are attached to or associated with the principles of formation of laws and regulations. The Court needs to emphasize that the assessment of the stages and standards referred to is carried out accumulatively. In this case, if at least one stage or one standard is not met from all stages or all existing standards, then a law can be said to be formally flawed in its formation. That is, a formal defect of the law has been sufficiently proven if there is a defect from all or several stages or standards of all stages or standards as long as the defect can be explained with arguments and undoubted evidence to assess and state the existence of a formal defect in the formation of the law.

From the explanation of the Constitutional Court above, the President's ratification of the Bill is not a formal defect, as also explained by the Constitutional Court in Decision No. 
79/PUU-XVII/2019 regarding the formal review of Law no. 19 of 2019 concerning the Second Amendment to Law No. 30 of 2002 concerning the Corruption Eradication Commission against the 1945 Constitution of the Republic of Indonesia:

"... the legal existence of a Bill becoming law is a "mutual agreement between the DPR and the President in level I and level II discussions" which juridically the legality of obtaining legality starts from the discussion at level I and ends at level II discussions. So "President's endorsement" or "President's signature" is no longer a process of obtaining the legality of a law but is one of the administrative processes for the enactment of a law which is the duty and responsibility of the President as head of state to carry out promulgation and disseminate a law so that it can be known publicly. general;"

The ratification referred to in Article 20 paragraph (5) of the 1945 Constitution of the Republic of Indonesia is only an administrative process that does not have any legal consequences. With the presence of Article 20 paragraph (5) of the 1945 Constitution of the Republic of Indonesia, the President's ratification of the Bill no longer provides validity as previously intended in Article 20 paragraph (4) of the 1945 Constitution of the Republic of Indonesia.

\section{Legality and Legitimacy of Laws Enacted Without Presidential Ratification}

During the Reformation era, there were seven bills that were promulgated without the approval of the President. These seven bills have become laws and are the object of cases in both material and formal examinations at the Constitutional Court. The President issues implementing regulations for the seven Laws. In Table 2 below, the petition for review to the Constitutional Court and its implementing regulations is presented.

Table 2

\section{Implementing Regulations and Material and Formal Examinations of Laws Enacted Without Presidential Ratification}

\begin{tabular}{|c|c|c|}
\hline Law & Implementing Regulation & $\begin{array}{l}\text { Material and Formal } \\
\text { Examinations at } \\
\text { Constitutional Court }\end{array}$ \\
\hline $\begin{array}{l}\text { Law No. } 25 \text { of } 2002 \text { concerning } \\
\text { the Establishment of the Riau } \\
\text { Archipelago Province }\end{array}$ & $\begin{array}{l}\text { - } \quad \text { Riau Islands Provincial Regulation No. } \\
4 \text { of } 2005 \text { concerning the Stipulation } \\
\text { of September } 24 \text { as the Anniversary of } \\
\text { the Riau Islands Province } \\
\text { - } \quad \text { Riau Islands Provincial Regulation No. } \\
09 \text { of } 2005 \text { concerning the } \\
\text { Establishment of the Organization and } \\
\text { Work Procedure of the Pakong Praja } \\
\text { Police Unit of the Riau Islands } \\
\text { Provincial Government }\end{array}$ & $\begin{array}{l}\text { No. 48/PUU-X/2012 } \\
\text { No. 62/PUU-X/2012 }\end{array}$ \\
\hline $\begin{array}{l}\text { Law No. } 32 \text { of } 2002 \text { concerning } \\
\text { Broadcasting }\end{array}$ & $\begin{array}{l}\text { - PP No. } 11 \text { of } 2005 \text { concerning the } \\
\text { Implementation of Broadcasting for } \\
\text { Public Broadcasting Institutions } \\
\text { - PP No. } 12 \text { of } 2005 \text { concerning the RI } \\
\text { Radio Public Broadcasting Institution } \\
\text { - PP No. } 13 \text { of } 2005 \text { concerning the } \\
\text { Republic of Indonesia Television } \\
\text { Public Broadcasting Institution } \\
\text { - PP No. } 49 \text { of } 2005 \text { concerning }\end{array}$ & $\begin{array}{l}\text { No. 005/PUU-I/2003 } \\
\text { No. 031/PUU-IV/2006 } \\
\text { No. 6/PUU-VII/2009 } \\
\text { No. 78/PUU-IX/2011 } \\
\text { No. 71/PUU-XI/2013 } \\
\text { No. 62/PUU-XIV/2016 } \\
\text { No. 81/PUU-XIV/2017 } \\
\text { No. 39/PUU- } \\
\text { XVIII/2020 }\end{array}$ \\
\hline
\end{tabular}


- Guidelines for Foreign Broadcasting Institutions Covering Activities

- PP No. 50 of 2005 concerning the Implementation of Private Broadcasting Institutions

- PP No. 51 of 2005 concerning the Implementation of Community Broadcasting Institutions

- PP No. 52 of 2005 concerning the Implementation of Broadcasting by Subscription Broadcasting Institutions

Law No. 18 of 2003 concerning PP No. 83 of 2008 concerning Requirements Advocates and Procedures for Providing Free Legal Aid

No. 019/PUU-I/2003

No. 006/PUU-II/2004

No. 009/PUU-IV/2006

No. 014/PUU-IV/2006

No. $015 / \mathrm{PUU}-\mathrm{IV} / 2006$

No. 101/PUU-VII/2009

No. 66/PUU-VIII/2010

No. $71 / \mathrm{PUU}-\mathrm{VIII} / 2010$

No. $79 / \mathrm{PUU}-\mathrm{VIII} / 2010$

No. $26 / P U U-X I / 2013$

No. $103 / \mathrm{PUU}-\mathrm{XI} / 2013$

No. 40/PUU-XII/2014

No. 112/PUU-XII/2014

No. 140/PUU-XII/2014

No. 32/PUU-XIII/2015

No. 36/PUU-XIII/2015

No. 84/PUU-XIII/2015

No. 95/PUU-XIV/2016

No. 89/PUU-XV/2017

No. 35/PUU-XVI/2018

No. 52/PUU-XVI/2018

No. 56/PUU-XVI/2018

No. 79/PUU-XVI/2018

Law No. 17 of 2003 concerning

State Finance
- PP No. 90 of 2010 concerning the Preparation of Work Plans and Budgets of State Ministries/Agencies

- PP No. 71 of 2010 concerning Government Accounting Standards
Law No. 24 of 2014 concerning the Election of Governors, Regents and Mayors

Notes:

Revoked by Government Regulation in Lieu of Law (Perpu) No. 1 of 2014 Law no. 2 of 2018 concerning the Second Amendment to Law No. 17 of 2014 concerning the MPR, DPR, DPD and DPRD
- MPR RI Decision No. 7 of 2018 on the Addition of MPR Leadership for the 2018-2019 Department

- Regulation of the House of Representatives of the Republic of Indonesia No. 1 of 2020 on Discipline
No. 28/PUU-IX/2011

No. 41/PUU-X/2012

No. 35/PUU-XI/2013

No. 62/PUU-XI/2013 No. 95/PUU-XI/2013 No. 97/PUU-XII/2014 No. 102/PUU-XII/2014 No. 98/PUU-XII/2014 No. 99/PUU-XII/2014 No. 103/PUU-XII/2014 No. 104/PUU-XII/2014 No. 105/PUU-XII/2014 No. 111/PUU-XII/2014 No. 16/PUU-XVI/2018 No. 17/PUU-XVI/2018 No. 21/PUU-XVI/2018 No. 25/PUU-XVI/2018 No. 26/PUU-XVI/2018 No. 28/PUU-XVI/2018 
Continuation Table 2

- DPD Regulation No. 2 of 2019 on

No. 34/PUU-XVI/2018

Discipline.

No. 37/PUU-XVI/2018

No. 39/PUU-XVI/2018

No. $17 / \mathrm{PUU}-\mathrm{XVII} / 2019$

No. 42/PUU-XVII/2019

Law no. 2 of 2018 concerning the Second Amendment to Law No. 17 of 2014 concerning the MPR, DPR, DPD and DPRD, Law No. 19 of 2019 concerning the Second Amendment to Law No. 30 of 2002 concerning the Corruption Eradication Commission
- $\quad$ Presidential Regulation No. 102 of 2020 concerning the Implementation of Supervision on the Eradication of Corruption Crimes

- Government Regulation No. 4 of 2020 concerning Procedures for Appointing the Chairperson and Members of the Supervisory Board of the Corruption Eradication Commission

- $\quad$ Presidential Regulation No. 91 of 2019 concerning the Implementing Organs of the Supervisory Board of the Corruption Eradication Commission
No. 57/PUU-XVII/2019 No. 59/PUU-XVII/2019 No. 62/PUU-XVII/2019 No. 70/PUU-XVII/2019 No. 71/PUU-XVII/2019 No. 73/PUU-XVII/2019 No. 77/PUU-XVII/2019 No. 79/PUU-XVII/2019 No. 84/PUU-XVII/2019

In addition to laws promulgated without ratification by the President, there are also laws which the Constitutional Court had declared in its entirety to be contrary to the 1945 Constitution and have no binding legal force. These five Laws were ratified by the President, namely: (1) Law no. 20 of 2002 concerning Electricity vide Constitutional Court Decision No. 001-021-022/PUU-I/2003, (2) Law no. 9 of 2009 concerning Educational Legal Entities vide Constitutional Court Decision No. 11-14-21-126-136/PUU-VII/2009, (3) Law no. 7 of 2004 concerning Water Resources vide Constitutional Court Decision No. 85/PUU-XI/2013, (4) Law no. 17 of 2012 concerning Cooperatives vide Constitutional Court Decision No.28/PUU$\mathrm{XI} / 2013$, and (5) the last conditionally unconstitutional for two years is Law no. 11 of 2020 concerning Job Creation vide Constitutional Court Decision No. 91/PUU-XVIII/2020.

\section{Conclusion}

1) Ratio legis or reason of law in modern law is associated with interpreting legal texts. Article 20 paragraph (5) has begun to be discussed in the first amendment to the 1945 Constitution, but has not reached an agreement at the time of ratification of the first amendment. Article 20 paragraph (5) which was ratified in the second amendment to the 1945 Constitution is a solution to the existence of Bills that have been approved by the DPR such as the Broadcasting Bill and the Handling Danger State (Penanggulangan Keadaan Bahaya) Bill, but were not ratified by the President. Taufieqqurochman from the F-TNI/Polri believes that if the President has already discussed the Bill with the DPR, then there is no reason for the President not to ratify the Bill, no matter what happens. The discussion of Article 20 paragraph (5) of the 1945 Constitution, as well as the entirety of Article 20 of the 1945 Constitution, shows a variety of changing logics of thought. Finally, the formulation of Article 20 paragraph (5) is one manifestation of the exercise of power to form laws that are in the hands of the DPR. Although the bill was not signed by the President, it did not reduce the commitment of all parties, especially state officials, to implement the law, including the President. This is because the law has previously been jointly approved by the DPR and the President. 
2) Of the seven Bills that were not ratified by the President, three Bills were proposed by the President, namely the Bill on Advocates, the Bill on State Finances, and the Bill on the Election of Governors, Regents and Mayors. In submitting these three Bills to the Speaker of the DPR, the President appoints the Minister of Justice and Human Rights to represent the Government in the discussion of the Law on Advocates, and the Minister of Finance to represent the Government in the discussion of the State Finance Bill. Likewise, the four Bills proposed by the DPR, namely the Bill on the Establishment of the Riau Islands Province, the Bill on Broadcasting, the Bill on the Election of Governors, Regents and Mayors, the Bill on the Second Amendment to Law no. 17 of 2014 concerning the MPR, DPR, DPD and DPRD, the Bill on the Second Amendment to Law no. 30 of 2002 concerning the Corruption Eradication Commission, the President in a reply to the Chairman of the DPR appointed each Minister representing the Government to discuss the five bills with the DPR.The President's view on the concept of ratification can be seen from several decisions of the Constitutional Court No. 005/PUU-I/2003, No. 17/PUU-XVI/2018, No. 79/PUU-XVII/2019. From the three decisions of the Constitutional Court above, it can be concluded that the President's views on the ratification are as follows:

a) There is no problem with the President's ratification of the Bill that has received mutual approval, because it will remain valid in accordance with Article 20 paragraph (5) of the 1945 Constitution of the Republic of Indonesia.

b) It is the President's policy choice to ratify or not to ratify a bill.

c) Ratification of the President on a bill that has been mutually agreed upon is one of the administrative processes for the enactment of a law. The legality of a bill becoming a law is subject to the joint approval of the DPR and the President.

3) Legality and legitimacy are two different concepts but they are intertwined in the process of forming laws. This is the same as the principle of popular sovereignty (democracy) and the rule of law (nomocracy) which are intertwined and should be implemented simultaneously like the same coin with two sides. The seven bills that were promulgated without the approval of the President, in terms of the principle of the hierarchy of norms, quoting Attamimi's opinion, are das Sollen for the regulations under them, are provisions that must be followed by lower norms. The seven laws have also undergone several material and formal trials at the Constitutional Court, as summarized in Table 2.

In addition to Bills that were not ratified by the President but were valid as objects of cases in the judicial review of the Law at the Constitutional Court, there are five laws passed by the President which became the objects of cases in the judicial review, namely: (1) Law no. 20 of 2002 concerning Electricity, (2) Law no. 9 of 2009 concerning Educational Legal Entities, (3) Law no. 7 of 2004 concerning Water Resources, (4) Law no. 17 of 2012 concerning Cooperatives, (5) Law no. 11 of 2020 concerning Job Creation. These four laws were declared by the Constitutional Court to be contrary to the 1945 Constitution and all of these laws did not have binding legal force, where Law no. 11 of 2020 is conditionally unconstitutional. So it can be understood that the President's ratification of the Bill does not have any impact on the legality and legitimacy of the formation of laws.

\section{Recommendation}

1) MPR need to revisit the grand design of the law-making mechanism that is in line with the original intent of the MPR to empower the DPR. The power to form laws and the legislative function of the DPR which is an inseparable unit raises the question of whether 
the President's ratification of the Bill is still relevant. The shift of power to form laws to the DPR should also be followed by changes to the mechanisms that follow it so that there is coherence and consistency in the selection of constitutional doctrine in executive-legislative relations in a presidential government system. The President's ratification of the bill, which is only an act and does not have any legal consequences, does not need to be included in the law-making procedure.

2) In strengthening the system of checks and balances in the Indonesian legislative system, MPR is necessary to reorganize the institutional relationship between the legislativeexecutive bodies, where after the third amendment to the 1945 Constitution a new legislative body emerged, namely the Regional Representative Council (DPD). Thus the system of representative institutions shifted to bicameral. The DPD as a regional representation that does not come from a political party is expected to act as counteract in the DPR-President relationship which is dominated by political parties that have the potential to create oligarchy or despotic. This can be a strengthening of representative institutions to become strong bicameralism. So that the resulting law is more aspirational and inclusive, especially for people who are vulnerable to the law. Broader political participation will increase political efficacy.

The shift in power to form laws to the DPR will of course also bring changes to the legal framework (kenvorm) of the Law. The position of legislator who has been with the President should be shifted to the DPR, or the DPR and DPD if there is a strengthening of the legislative function of the DPD that is balanced with the DPR. The legislator body should make an amendment to the preamble of the Law. Likewise with legislation, to be in the legislative environment which is monitored by the Legislative Body (Badan Legislasi) whose existence is an embodiment of the spirit of the Constitution which stipulates that the DPR as the holder of the power to form laws

\section{References}

1. Ridwan HR. 2007. Hukum Administrasi Negara. Jakarta, PT Raja Grafindo Persada.

2. Garner B.A. 2009. Black's Law Dictionary. ninth edition. St. paul, WesT.

3. Schmitt C. 2004. Legality and Legitimacy. Durham \& London, Duke University Press.

4. Rousseau, J.J. 1999. The Social Contract. Oxford, Oxford University Press.

5. Hardiman, F.B. 2019. Demokrasi Deliberatif. Jogjakarta, PT. Kanisius.

6. Indrati M.F.S. 2011. Ilmu Perundang-undangan. Fifth Printed. Bandung, Penerbit Kanisius.

7. Raz J. 2002. Practical Reason and Norms. Oxford, Oxford University Press.

8. Kelsen H. 2005. General Theoy of Law and State. 1st Edition. France, Routledge.

9. Hudson A. 2021. The Veil of Partcipation, Citizens and Political Partners in Constitution-Making Process. Cambridge, Cambridge University Press.

10. Asshiddiqie J \& Safa'at, M.A. 2012. Teori Hans Kelsen Tentang Hukum. Jakarta, Konpress.

11. Kusnardi, M. \& Ibrahim, H. 2010. Pengantar Hukum Tata Negara Indonesia. Depok, Pusat Studi Hukum Tata Negara, Fakultas Hukum Universitas Indonesia, cetakan ke-12.

12. Hague R. \& Harrop M. 2004. Comparative Government and Politics, An Introduction. 6th edition. New York, Palgrave Macmillan.

13. Panao R.A.L. 2014. Beyond roll call: executive-legislative relations and lawmaking in the Philippine House of Representatives. Philippine Political Science Journal, 13(3), pp. 1751 - 6242,

14. Manan B. 2003.Lembaga Kepresidena, Yogyakarta, FH UII Press.

15. Montesquieu. 1989. The Spirit of the Laws, translated and edited by Anne M. Cohler, Basia Carolyn Miller, Harold Samuel Stone. Cambridge, Cambdrige University Press.

16. Sullivan J.V. 2007. Parliamentarian, U.S. House of Representatives, How Our Laws Are Made. Washington, US Government Printing Office. 
17.Lijphart, A. 2012. Patterns of Democracy, Government Forms and Performance in Thirty-Six Countries. New Haven \& London, Yale University Press.

18. Sellick, J. 2010. Key Facts Constiutional and Administrative Law. Hodder Education, UK, 4th edition.

19. Duverger, M. 1980. A New Political System Model: Semi-Presidential Government. European Journal of Poitical Research, 8(2), pp. 165-264. https://doi.org/10.1111/j.1475-6765.1980.tb00569.x

20. Saragih, B. 1988. Lembaga Perwakilan Dan Pemilihan Umum Di Indonesia. Jakarta, Gaya Media Pratama, cetakan pertama.

\section{Laws and Regulations}

1. Association of Secretaries General of Parliament, Constitutional and Parliamentary Information, $3^{\text {rd }}$ Series, No. 16911st Half-year-1995, Forty-fifth year, p. 5: The Government comprises the Prime Minister, the Ministers and, as the need arises, the Secretaries of State. The Prime Minister is appointed by the President of the Republic. The Ministers and the Secretaries of State are appointed by the President of the Republic on the proposition of the Prime Minister.

2. British Constitution, Article 52.1, The legislative power in the United Kingdom is vested in Parliament and the Assemblies.

3. British Constitution, Article 34.1.1, There is established by this Constitution the office of Head of State of the United Kingdom, which is held by Her Majesty Queen Elizabeth II and Her Heirs and Successors.

4. British Constitution. Article 36, Duties of the Head of State. 36.1 The Head of State shall - (4) signify Assent to all Bills which, in accordance with this Constitution and the law and custom of Parliament, have passed through their stages in Parliament and are presented to the Head of State for Assent;

5. British Constitution. Article 40, The executive power in the United Kingdom. 40.1 The executive power for the United Kingdom is vested in, and, subject to this Constitution, shall be exercised by, the Government of the United Kingdom. 40.2 There is established by this Constitution a Government for the United Kingdom, which shall comprise - (1) the Prime Minister; and (2) the members of Parliament appointed as the Ministers of the Government.

6. French Constitution 1958, Article 6, The President of the Republic shall be elected for a term of five years by direct universal suffrage. No one may hold office for more than two consecutive terms. The manner of implementation of this article shall be determined by an Institutional Act.

7. French Constitution 1958, Article 8, The President of the Republic shall appoint the Prime Minister. He shall terminate the appointment of the Prime Minister when the latter tenders the resignation of the Government. On the recommendation of the Prime Minister, he shall appoint the other members of the Government and terminate their appointments.

8. French Constutution 1958, Article 20 The Government shall determine and conduct the policy of the Nation. It shall have at its disposal the civil service and the armed forces. It shall be accountable to Parliament in accordance with the terms and procedures set out in articles 49 and 50.

9. French Constitution 1958, Article 0, The President of the Republic shall preside over the Council of Ministers.

10. French Constitution 1958, Article 24, Parliament shall pass statutes.

11. Indonesia, Decision of the Constitutional Court of the Republic of Indonesia No. 17/PUU-XVI/2018.

12. Indonesia, Putusan Mahkamah Konstitusi No. 25/PUU-XIII/2015.

13. Indonesia, Constitutional Court Decision No. 85/PUU-XI/2013.

14. Indonesia, Decision of Constitutional Court RI No. 91/PUU-XVII/2020

15. Service Des Affaires Internationales Et De Defense, The National Assembly In The French Institutions, Paris, Februari 2013, p. 205: Bills initiated by the Prime Minister are called "projets de loi" or Government bills, whilst those initiated by parliamentarians are referred to as "propositions de loi" or Members' bills.

16. US Constitution, Article I. Section 1. All legislative Powers herein granted shall be vested in a Congress of the United States, which shall consist of a Senate and House of Representatives.

17. US Constitution, Article 1, Section 7, para 2: Every Bill which shall have passed the House of Representatives and the Senate, shall, before it become a Law, be presented to the President of the United States; If he approve he shall sign it, but if not he shall return it, with his Objections to that House in which it shall have originated, who shall enter the Objections at large on their Journal, and proceed to reconsider it. 